\title{
Virgibacillus subterraneus sp. nov., a moderately halophilic Gram-positive bacterium isolated from subsurface saline soil
}

Correspondence

Yanfen Xue

xueyf@im.ac.cn

\author{
Xiaowei Wang, ${ }^{1,2}$ Yanfen $\mathrm{Xue}^{1}$ and Yanhe $\mathrm{Ma}^{1}$ \\ ${ }^{1}$ State Key Laboratory of Microbial Resources, Institute of Microbiology, Chinese Academy of
Sciences, Beijing 100101, PR China \\ ${ }^{2}$ Graduate University of the Chinese Academy of Sciences, Beijing 100049, PR China
}

A Gram reaction-positive, moderately halophilic bacterium, designated $\mathrm{H}^{5} 7 \mathrm{~B} 72^{\top}$, was isolated from subsurface saline soil of Qaidam basin in the Qinghai province, China. Cells were rodshaped, strictly aerobic, spore-forming and motile. The isolate grew optimally at $9 \%(\mathrm{w} / \mathrm{v}) \mathrm{NaCl}$, $\mathrm{pH} 7.5$ and $30^{\circ} \mathrm{C}$. The cell-wall peptidoglycan of strain $\mathrm{H} 57 \mathrm{~B} 72^{\top}$ contained mesodiaminopimelic acid as the diagnostic diamino acid. The predominant isoprenoid quinone was MK-7. The major cellular fatty acids were anteiso- $\mathrm{C}_{15: 0}(59.97 \%)$ and anteiso- $\mathrm{C}_{17: 0}(17.14 \%)$. Phosphatidylglycerol, diphosphatidylglycerol and a glycolipid were found to be the predominant polar lipids. The genomic DNA G $+\mathrm{C}$ content of strain $\mathrm{H} 57 \mathrm{~B} 72^{\top}$ was $37.1 \mathrm{~mol} \%$. $16 \mathrm{~S}$ rRNA gene sequence analysis showed that strain $\mathrm{H} 57 \mathrm{~B} 72^{\top}$ was a member of the genus Virgibacillus and was most closely related to Virgibacillus salinus DSM $21756^{\top}$ (98.3\% gene sequence similarity). The level of DNA-DNA relatedness between strain $\mathrm{H}^{\top} 7 \mathrm{~B} 72^{\top}$ and $V$. salinus DSM $21756^{\top}$ was $8.5 \%$. Based on the phenotypic, genotypic and phylogenetic data presented, strain H57B72 ${ }^{\top}$ represents a novel species, for which the name Virgibacillus subterraneus sp. nov. is

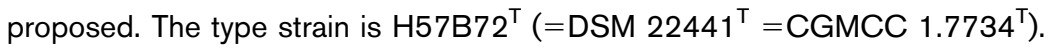

The genus Virgibacillus was first proposed by Heyndrickx et al. (1998) with the transfer of Bacillus pantothenticus to Virgibacillus pantothenticus based on data from polyphasic studies; its description was later emended by Heyrman et al. (2003). At the time of writing, a total of 18 Virgibacillus species have been described: the mesophile $V$. pantothenticus, isolated from soil (type species of the genus) (Heyndrickx et al., 1998), V. proomii from a water supply (Heyndrickx et al., 1999), V. carmonensis and V. necropolis from a deteriorated mural painting (Heyrman et al., 2003), V. marismortui from Dead Sea water (Arahal et al., 1999, 2000; Heyrman et al., 2003), V. salexigens from a saltern and from hypersaline soils (Garabito et al., 1997; Heyrman et al., 2003), V. halodenitrificans from a saltern (Yoon et al., 2004), V. dokdonensis from seawater (Yoon et al., 2005), V. koreensis from a salt field (Lee et al., 2006), V. olivae from the wastewater of green olive processing (Quesada et al., 2007), V. halophilus from field soil (An et al., 2007), V. chiguensis from a disused salt field (Wang et al., 2008), V.

Abbreviation: RAPD, random amplification of polymorphic DNA.

The GenBank/EMBL/DDBJ accession number for the 16S rRNA gene sequence of strain $\mathrm{H}^{57 B 72}{ }^{\top}$ is $\mathrm{FJ} 746573$.

A phase-contrast micrograph of cells of strain $\mathrm{H} 57 \mathrm{~B} 72^{\top}$ and RAPD fingerprints of strains $\mathrm{H}_{57 B} 72^{\top}$ and $V$. salinus DSM $21756^{\top}$ are available as supplementary data with the online version of this paper. salarius from a salt lake (Hua et al., 2008), V. kekensis from saline mud (Chen et al., 2008), V. sediminis from a salt lake (Chen et al., 2009), V. arcticus from permafrost in the Canadian high Arctic (Niederberger et al., 2009), V. byunsanensis from a marine solar saltern (Yoon et al., 2010) and $V$. salinus from the sediment of a salt lake (Carrasco et al., 2009).

During the course of a study on the microbial diversity of subsurface saline soil samples taken at a scientific drilling site ( $\left.37^{\circ} 03^{\prime} 50^{\prime \prime} \mathrm{N} 94^{\circ} 43^{\prime} 41^{\prime \prime} \mathrm{E}\right)$ in the Qaidam basin, China, large numbers of halophilic bacteria were isolated. Phylogenetic analysis based on 16S rRNA gene sequence comparisons showed that most of the moderately halophilic isolates were found to be related to the genera Bacillus, Salinicoccus, Marinobacter, Halomonas, Idiomarina, Halolactibacillus, Halobacillus, Thalassobacillus and Virgibacillus. In this study, we present the taxonomic characterization of a Virgibacillus-like strain, $\mathrm{H}_{57} \mathrm{~B} 72^{\mathrm{T}}$.

Strain $\mathrm{H} 57 \mathrm{~B} 72^{\mathrm{T}}$ was isolated from a subsurface saline soil sample by using the standard dilution-plating technique on SG agar (Sehgal \& Gibbons, 1960), containing the following $\left(\mathrm{g} \mathrm{l}^{-1}\right)$ : Casamino acids (Difco), 7.5; yeast extract (Difco), 10; sodium glutamate, 1 ; trisodium citrate, $3 ; \mathrm{MgSO}_{4} .7 \mathrm{H}_{2} \mathrm{O}$, 20; KCl, 2; $\mathrm{NaCl}, 80 ; \mathrm{FeSO}_{4} .7 \mathrm{H}_{2} \mathrm{O}, 0.036 ; \mathrm{MnCl}_{2} .4 \mathrm{H}_{2} \mathrm{O}$, 0.00036 . The medium was adjusted to $\mathrm{pH} 8.0$ with $1 \mathrm{M}$ 
$\mathrm{NaOH}$ before autoclaving and was solidified by the addition of $2.0 \%(\mathrm{w} / \mathrm{v})$ agar. Strain $\mathrm{H} 57 \mathrm{~B} 72^{\mathrm{T}}$ was maintained in liquid SG medium supplemented with $30 \%(\mathrm{v} / \mathrm{v})$ glycerol at $-80{ }^{\circ} \mathrm{C}$ for long-term preservation. Strain $\mathrm{H} 57 \mathrm{~B} 72^{\mathrm{T}}$ was routinely cultured on growth medium (GM, pH 7.5) containing the following $\left(\mathrm{g} \mathrm{l}^{-1}\right)$ : Casamino acids (Difco), 5; yeast extract (Difco), $5 ; \mathrm{NaCl}, 90 ; \mathrm{MgSO}_{4} .7 \mathrm{H}_{2} \mathrm{O}, 2$ and $\mathrm{KCl}, 2$ (Wang et al., 2009).

To characterize strain $\mathrm{H} 57 \mathrm{~B} 72^{\mathrm{T}}$, standard phenotypic tests were performed. Virgibacillus salinus DSM $21756^{\mathrm{T}}$ was kindly provided by Professor A. Ventosa (University of Seville, Spain) and used as a reference strain for comparative phenotypic studies. The morphology, pigmentation and size of colonies were observed under optimal growth conditions on GM agar after $48 \mathrm{~h}$ of incubation at $30^{\circ} \mathrm{C}$. Cell morphology and motility were examined by phase-contrast and transmission electron microscopy. Gram-type was determined by the staining method (Dussault, 1955) and the $\mathrm{KOH}$ lysis method (Gregersen, 1978). The range of $\mathrm{NaCl}$ concentration for growth was determined in modified liquid GM medium with $0,1,3,5,7,9,12,16,20,22,25$ and $30 \%$ $(\mathrm{w} / \mathrm{v}) \mathrm{NaCl}$. The $\mathrm{pH}$ range for growth was tested at intervals of $0.5 \mathrm{pH}$ units in liquid GM medium buffered with $50 \mathrm{mM}$ MES (pH 5.0-6.5), PIPES (pH 6.5-7.5), HEPES (pH 7.08.0), Tricine (pH 7.5-9.0) and CHES ( $\mathrm{pH} 9.0-10.0$ ). Growth at $4,10,15,20,25,30,37,40,45$ and $50{ }^{\circ} \mathrm{C}$ was determined in liquid GM medium. The ability of the strain to grow anaerobically was evaluated by streaking on plates of GM agar or inoculation of liquid GM medium supplemented with nitrate $\left(5 \mathrm{~g} \mathrm{l}^{-1}\right)$ and incubation in a gaseous atmosphere of $100 \% \mathrm{~N}_{2}$ in anaerobic chambers. The level of growth was checked after 5, 10 and 15 days of incubation. Sporulation ability was assessed on GM agar supplemented with $5 \mathrm{mg} \mathrm{MnSO} \mathrm{I}^{-1}$. Plates were inoculated and incubated at $30{ }^{\circ} \mathrm{C}$ for up to 2 weeks to determine the presence of endospores. API $50 \mathrm{CH}$ test strips (Analytab Products, bioMérieux) were used to examine the assimilation of carbohydrates and the production of acid as recommended by the manufacturer, but with a modification that the suspension medium supplied by bioMérieux and used to resuspend cells of strain $\mathrm{H} 57 \mathrm{~B} 72^{\mathrm{T}}$ was supplemented with $9 \%(\mathrm{w} / \mathrm{v}) \mathrm{NaCl}$. Tests for other biochemical characteristics, listed in Table 1 or included in the species description, were performed according to previously described methods (Smibert \& Krieg, 1981; Ventosa et al., 1982). Unless otherwise indicated, all tests were carried out in triplicate and under optimal growth conditions. Growth in liquid medium was monitored at $\mathrm{OD}_{600}$. Susceptibility to antimicrobial agents was tested by spreading exponential-phase cultures on GM agar medium plates with absorbent paper discs impregnated with antimicrobial agents. Zones of inhibition were determined after incubation at $30{ }^{\circ} \mathrm{C}$ for 2 days.

Cells of strain $\mathrm{H} 57 \mathrm{~B} 72^{\mathrm{T}}$ were Gram reaction-positive, rodshaped, motile and endospore-forming (Supplementary Fig. S1, available in IJSEM Online). The strain displayed phenotypic characteristics typical of the genus Virgibacillus,
Table 1. Characteristics that distinguish strain $\mathrm{H} 57 \mathrm{~B} 72^{\top}$ from related species of the genus Virgibacillus

Taxa: 1, strain $\mathrm{H} 57 \mathrm{~B} 72^{\mathrm{T}}$ (data from this study); 2, V. salinus (Carrasco et al., 2009); 3, V. carmonensis (Heyrman et al., 2003); 4, V. necropolis (Heyrman et al., 2003); 5, V. byunsanensis (Yoon et al., 2010); 6, V. arcticus (Niederberger et al., 2009). All species are rod-shaped, motile, strictly aerobic and positive for catalase activity. $\mathrm{W}$, Weakly positive; ND, no data available.

\begin{tabular}{|c|c|c|c|c|c|c|}
\hline Characteristics & 1 & 2 & 3 & 4 & 5 & 6 \\
\hline Spore shape ${ }^{\star}$ & $\mathrm{E} / \mathrm{s}$ & $\mathrm{E} / \mathrm{s}$ & $\mathrm{E} / \mathrm{s}$ & $\mathrm{E}$ & s/o & $\mathrm{E}$ \\
\hline Spore position $\dagger$ & $\mathrm{T}$ & S/T & $\mathrm{s}$ & $\mathrm{C} / \mathrm{T} / \mathrm{s}$ & $\mathrm{T}$ & $\mathrm{c} / \mathrm{s}$ \\
\hline $\begin{array}{l}\text { Temperature range } \\
\left({ }^{\circ} \mathrm{C}\right)\end{array}$ & $10-50$ & $15-40$ & $10-40$ & $10-40$ & $4-40$ & $0-30$ \\
\hline \multicolumn{7}{|l|}{ Growth in: } \\
\hline $0.5 \%(\mathrm{w} / \mathrm{v}) \mathrm{NaCl}$ & + & - & - & $\mathrm{W}$ & + & + \\
\hline $25 \%(\mathrm{w} / \mathrm{v}) \mathrm{NaCl}$ & + & - & - & - & - & - \\
\hline Oxidase & + & - & + & ND & + & - \\
\hline $\mathrm{H}_{2} \mathrm{~S}$ production & + & - & - & - & - & - \\
\hline \multicolumn{7}{|l|}{ Hydrolysis of: } \\
\hline Starch & - & - & - & - & + & ND \\
\hline Casein & - & - & + & + & - & + \\
\hline Gelatin & - & - & - & $\mathrm{w}$ & - & + \\
\hline Aesculin & + & + & $\mathrm{w}$ & - & - & $\mathrm{ND}$ \\
\hline Tween 80 & - & + & - & $\mathrm{w}$ & - & ND \\
\hline \multicolumn{7}{|l|}{ Acid production from: } \\
\hline Glycerol & + & - & - & $\mathrm{w}$ & - & ND \\
\hline D-Galactose & + & + & - & - & + & ND \\
\hline D-Glucose & + & + & - & $\mathrm{w}$ & - & $\mathrm{W}$ \\
\hline D-Fructose & + & + & - & $\mathrm{W}$ & $\mathrm{w}$ & $\mathrm{w}$ \\
\hline Trehalose & - & + & - & $\mathrm{w}$ & - & + \\
\hline $\begin{array}{l}\text { DNA G + C content } \\
(\mathrm{mol} \%)\end{array}$ & 37.1 & 38.8 & 38.9 & 37.4 & 37.6 & 38.2 \\
\hline
\end{tabular}

${ }^{\star} \mathrm{E}$, Ellipsoidal; s, spherical; O, oval.

$\dagger \mathrm{C}$, Central; s, subterminal; $\mathrm{T}$, terminal.

details of which are presented in the species description, but there are some differences between the phenotypic characteristics of strain $\mathrm{H} 57 \mathrm{~B} 72^{\mathrm{T}}$ and those of other recognized Virgibacillus species (Table 1). In particular, strain $\mathrm{H} 57 \mathrm{~B} 72^{\mathrm{T}}$ is clearly distinct from $V$. salinus DSM $21756^{\mathrm{T}}$, its phylogenetically closest neighbour, differing in the range of $\mathrm{NaCl}$ concentrations and temperatures suitable for growth, Tween 80 hydrolysis, $\mathrm{H}_{2} \mathrm{~S}$ production, oxidase activities, acid production from some substrates, some of the substrates used as sole carbon and energy sources and susceptibility to some antimicrobial agents.

Preparation of the cell wall and determination of peptidoglycan structure were performed by using the methods described by Schleifer \& Kandler (1972) with the modification that TLC on cellulose sheets was used instead of paper chromatography. Respiratory quinones were extracted according to the method of Collins et al. (1977) and analysed by reversed-phase HPLC (Groth et al., 1996). Polar lipids were extracted and identified by 
one-dimensional TLC followed by spraying with appropriate detection reagents (Torreblanca et al., 1986). Fatty acids were extracted, methylated and analysed by GC using the standard Sherlock MIDI (Microbial Identification) system (Sasser, 1990; Kämpfer \& Kroppenstedt, 1996). The genomic DNA $\mathrm{G}+\mathrm{C}$ content was determined by the thermal denaturation method according to Marmur \& Doty (1962). Cell mass used for procedures mentioned above was obtained by cultivating strain $\mathrm{H} 57 \mathrm{~B} 72^{\mathrm{T}}$ and reference strain V. salinus DSM $21756^{\mathrm{T}}$ at $30{ }^{\circ} \mathrm{C}$ on GM agar.

Strain $\mathrm{H} 57 \mathrm{~B} 72^{\mathrm{T}}$ possessed peptidoglycan type $\mathrm{A} 1 \gamma$ with meso-diaminopimelic acid as the diagnostic diamino acid. The isoprenoid quinone detected in strain $\mathrm{H} 57 \mathrm{~B} 72^{\mathrm{T}}$ was menaquinone-7 (MK-7), as in other members of the genus Virgibacillus (Heyndrickx et al., 1998; Heyrman et al., 2003). The cellular polar lipids were diphosphatidylglycerol, phosphatidylglycerol and a glycolipid. Comparative analysis results based on one-dimensional TLC indicated that the profile of cellular polar lipid components of strain $\mathrm{H} 57 \mathrm{~B} 72^{\mathrm{T}}$ was the same as that of $V$. salinus DSM $21756^{\mathrm{T}}$. The major fatty acids in cells of strain $\mathrm{H} 57 \mathrm{~B} 72^{\mathrm{T}}$ were branched fatty acids anteiso- $\mathrm{C}_{15: 0}(59.97 \%)$, anteiso- $\mathrm{C}_{17: 0}(17.14 \%)$, iso$\mathrm{C}_{16: 0}(7.69 \%)$ and iso- $\mathrm{C}_{15: 0}(6.01 \%)$, similar to those of the type strains of other recognized species of the genus Virgibacillus. These chemotaxonomic data are in accordance with those described for the genus Virgibacillus (Heyrman et al., 2003; Heyndrickx et al., 1998).
Genomic DNA of strain $\mathrm{H} 57 \mathrm{~B} 72^{\mathrm{T}}$ was extracted using the method described by Marmur (1961). The 16S rRNA gene was amplified by PCR using the universal bacterial primers $8 \mathrm{~F}$ and $1492 \mathrm{R}$ as described previously (Duckworth et al., 1996). The almost-complete nucleotide sequence (1481 bp) was determined by direct sequencing and compared with available $16 \mathrm{~S}$ rRNA gene sequences in the GenBank database by using the BLAST program. Multiple alignments with closely related species were performed by using the program CLUSTAL_X (Thompson et al., 1997). Ambiguous and unalignable bases were manually omitted and then the phylogenetic tree was constructed from the evolutionary distance matrix calculated by using the neighbour-joining, minimum-evolutionary and maximum-parsimony methods in the program MEGA version 3.1 (Kumar et al., 2004). The robustness of the resultant tree topology was evaluated by bootstrap resampling analysis with 1000 replicates. This phylogenetic analysis revealed that strain $\mathrm{H} 57 \mathrm{~B} 72^{\mathrm{T}}$ was most closely related to $V$. salinus DSM $21756^{\mathrm{T}}$, with a $16 \mathrm{~S}$ rRNA gene sequence similarity value of $98.3 \%$, and had less than $95.2 \%$ similarity to other recognized species of the genus Virgibacillus. The phylogenetic tree based on the neighbourjoining method (Fig. 1) showed that strain $\mathrm{H} 57 \mathrm{~B} 72^{\mathrm{T}}$ clustered with $V$. salinus DSM $21756^{\mathrm{T}}$. Topologies of phylogenetic trees constructed using the minimum-evolutionary and maximum-parsimony algorithms were similar to that of the tree constructed using neighbour-joining analysis (not shown).

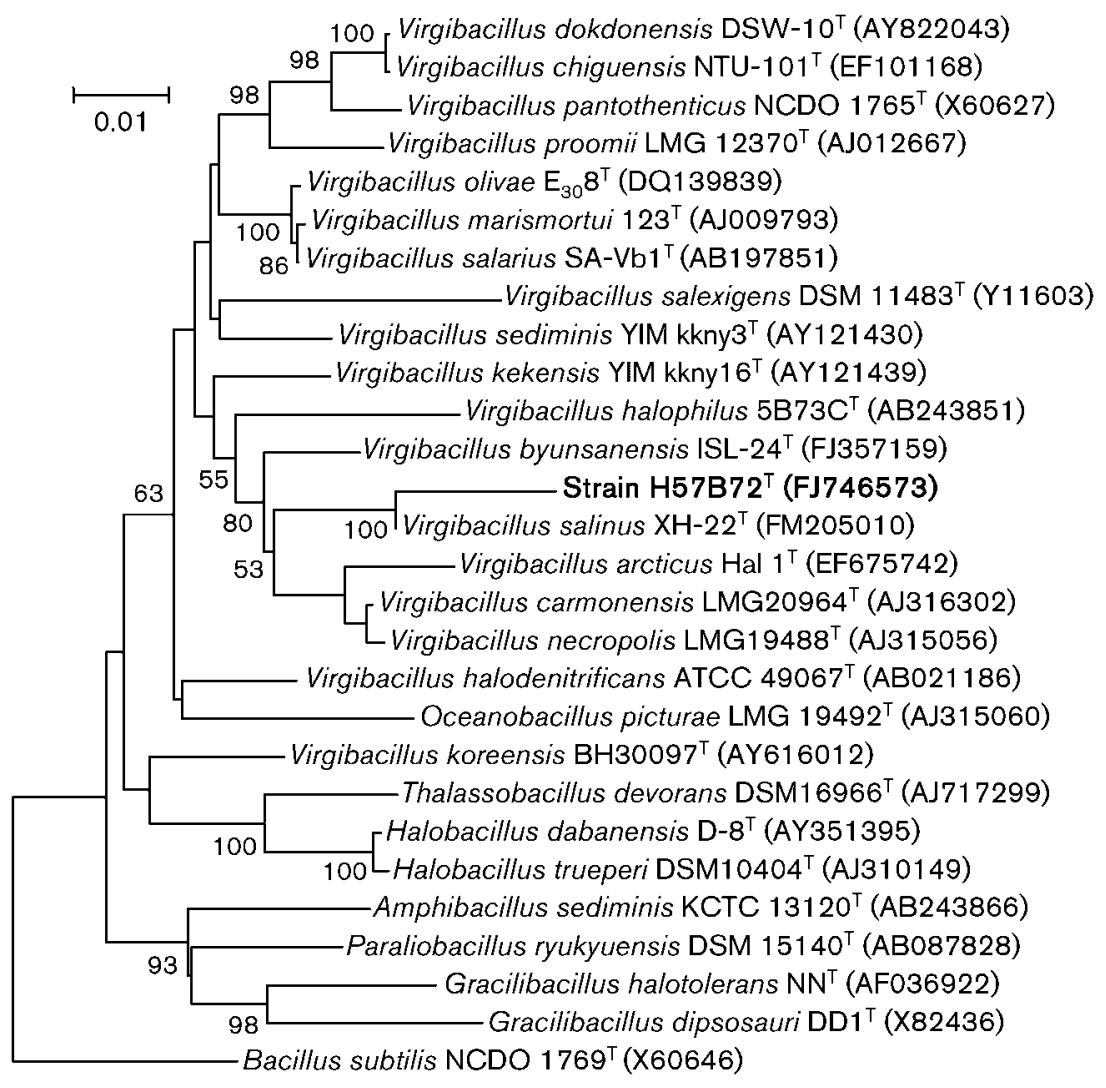

Fig. 1. Phylogenetic tree showing the relationships between strain $\mathrm{H} 57 \mathrm{~B} 72^{\mathrm{T}}$ and related strains based on 16S rRNA gene sequences. Numbers at nodes represent levels of bootstrap support (\%) based on a neighbourjoining analysis of 1000 resampled datasets. Accession numbers are given in parentheses. Bar, $1 \%$ sequence divergence. 
Random amplification of polymorphic DNA (RAPD) analysis was used to compare the genomic profile of strains $\mathrm{H} 57 \mathrm{~B} 72^{\mathrm{T}}$ and V. salinus DSM $21756^{\mathrm{T}}$ as described by Chao et al. (2008). RAPD analysis of strain $\mathrm{H} 57 \mathrm{~B} 72^{\mathrm{T}}$ showed a significantly different gel pattern from that of $V$. salinus DSM $21756^{\mathrm{T}}$ (Supplementary Fig. S2), indicating that the genomic profile of strain $\mathrm{H} 57 \mathrm{~B} 72^{\mathrm{T}}$ was different from that of $V$. salinus DSM $21756^{\mathrm{T}}$. DNA-DNA hybridization was performed by the spectrophotometric renaturation rate method (Huß et al., 1983; De Ley et al., 1970); the level of genomic DNA-DNA relatedness between strain $\mathrm{H} 57 \mathrm{~B} 72^{\mathrm{T}}$ and V. salinus DSM $21756^{\mathrm{T}}$ was $8.5 \%$ (mean of three independent experiments, which did not differ by more than $1.1 \%$ ). This value was far below the threshold value of $70 \%$ recommended for assigning strains to the same species (Wayne et al., 1987; Stackebrandt \& Goebel, 1994).

Overall, based on the evidence above, strain $\mathrm{H} 57 \mathrm{~B} 72^{\mathrm{T}}$ represents a novel species of the genus Virgibacillus for which the name Virgibacillus subterraneus sp. nov. is proposed.

\section{Description of Virgibacillus subterraneus sp. nov.}

Virgibacillus subterraneus (sub.ter.ra'ne.us. L. masc. adj. subterraneus underground, subterranean, indicating the source of isolation of the type strain).

Cells are Gram reaction-positive rods $(0.1-0.3 \times 1.0$ $3.0 \mu \mathrm{m}$ ), strictly aerobic, spore-forming and motile by means of peritrichous flagella. Cells occur singly, in pairs or as short chains. Ellipsoidal or spherical endospores form terminally in swollen sporangia. After cultivation on GM agar at $30{ }^{\circ} \mathrm{C}$ for 2 days, colonies are circular with slightly irregular margins, cream, opaque, slightly convex, 2.0$3.0 \mathrm{~mm}$ in diameter. After 3 days, the colonies turn slightly light-yellow. Grows at $10-50{ }^{\circ} \mathrm{C}$ (optimum $30{ }^{\circ} \mathrm{C}$ ) and at $\mathrm{pH}$ 6.0-9.0 (optimum $\mathrm{pH}$ 7.5). Grows at $\mathrm{NaCl}$ concentrations between 0 and $25 \%(\mathrm{w} / \mathrm{v})$ with optimum growth at $9 \%(\mathrm{w} / \mathrm{v}) \mathrm{NaCl}$. Positive for oxidase and catalase activities, methyl red reaction, $\mathrm{H}_{2} \mathrm{~S}$ production and gelatinase activity, but is negative for Voges-Proskauer reaction, indole production and urease, protease, pullulanase, amylase, lipase, DNase, phosphatase and $\beta$-glucosidase activities. Cells are able to reduce nitrate to nitrite aerobically but growth does not occur under anaerobic conditions in liquid GM medium supplemented with nitrate. Utilizes glucose by oxidative metabolism. Produces acids from glycerol, D-xylose, D-glucose, D-fructose, Dmannose, $\mathrm{N}$-acetylglucosamine, amygdalin, aesculin, cellobiose, maltose, sucrose, melezitose, raffinose, glycogen, xylitol, gentiobiose, turanose, D-arabitol, potassium 5ketogluconate, D- and L-arabinose, D-galactose, L-sorbose, L-rhamnose, arbutin, melibiose, D-sorbitol, erythritol, Dribose, L-xylose, D-adonitol, methyl $\beta$-D-xylopyranoside, dulcitol, inositol, methyl $\alpha$-D-glucopyranoside, inulin, lactose, lyxose, D-tagatose, D- and L-fucose, $\mathrm{L}$-arabitol and methyl $\alpha$-D-mannopyranoside, but not from D-mannitol, salicin, trehalose, 2-ketogluconate, potassium gluconate and starch. The following compounds are utilized as sole carbon and energy sources: glycerol, erythritol, D- and L-arabinose, D-xylose, D-adonitol, D-galactose, D-glucose, D-fructose, Dmannose, L-rhamnose, dulcitol, myo-inositol, D-sorbitol, cellobiose, maltose, lactose, melibiose, sucrose, inulin, raffinose and glycogen. The following compounds are not utilized as sole carbon and energy sources: trehalose, Dmannitol, salicin and potassium gluconate. Cells are susceptible to ( $\mu$ g unless specified otherwise): ampicillin (10), penicillin $\mathrm{G}(10 \mathrm{U})$, cefazolin (30), gentamicin (10), streptomycin (10), tetracycline (30), chloramphenicol (30), clindamycin (2), erythromycin (15), norfloxacin (10), vancomycin (30), ciprofloxacin (5), kanamycin (30), neomycin (30), polymyxin B (300 U), rifampicin (5), spectinomycin (100), josamycin (15), medicamycin (15), bacitracin $(0.04 \mathrm{U})$ and novobiocin (5). Cell-wall peptidoglycan type Al $\gamma$ with meso-diaminopimelic acid as the diagnostic diamino acid. The predominant cellular fatty acids are anteiso- $\mathrm{C}_{15: 0}$ and anteiso- $\mathrm{C}_{17: 0}$. The predominant isoprenoid quinone is menaquinone-7 (MK-7). The genomic DNA $\mathrm{G}+\mathrm{C}$ content of the type strain is $37.1 \mathrm{~mol} \%\left(T_{\mathrm{m}}\right)$.

The type strain, $\mathrm{H} 57 \mathrm{~B} 72^{\mathrm{T}}\left(=\mathrm{DSM} 22441^{\mathrm{T}}=\mathrm{CGMCC}\right.$ $1.7734^{\mathrm{T}}$ ), was isolated from a subsurface saline soil sample of the Qaidam basin, China.

\section{Acknowledgements}

This work was supported by grants from the Chinese Academy of Sciences (Knowledge Innovation program, KSCX2-YW-G-011) and the Ministry of Science and Technology of China (973 Program, 2007CB707801; 863 Programs: 2006AA020201 and 2007AA021306).

\section{References}

An, S. Y., Asahara, M., Goto, K., Kasai, H. \& Yokota, A. (2007). Virgibacillus halophilus sp. nov., spore-forming bacteria isolated from soil in Japan. Int J Syst Evol Microbiol 57, 1607-1611.

Arahal, D. R., Márquez, M. C., Volcani, B. E., Schleifer, K. H. \& Ventosa, A. (1999). Bacillus marismortui sp. nov., a new moderately halophilic species from the Dead Sea. Int J Syst Bacteriol 49, 521-530.

Arahal, D. R., Márquez, M. C., Volcani, B. E., Schleifer, K. H. \& Ventosa, A. (2000). Reclassification of Bacillus marismortui as Salibacillus marismortui comb. nov. Int J Syst Evol Microbiol 50, 1501-1503.

Carrasco, I. J., Márquez, M. C. \& Ventosa, A. (2009). Virgibacillus salinus sp. nov., a moderately halophilic bacterium from sediment of a saline lake. Int J Syst Evol Microbiol 59, 3068-3073.

Chao, S. H., Tomii, Y., Sasamoto, M., Fujimoto, J., Tsai, Y. C. \& Watanabe, K. (2008). Lactobacillus capillatus sp. nov., a motile Lactobacillus species isolated from stinky tofu brine. Int J Syst Evol Microbiol 58, 2555-2559.

Chen, Y. G., Cui, X. L., Fritze, D., Chai, L. H., Schumann, P., Wen, M. L., Wang, Y. X., Xu, L. H. \& Jiang, C. L. (2008). Virgibacillus kekensis sp. nov., a moderately halophilic bacterium isolated from a salt lake in China. Int J Syst Evol Microbiol 58, 647-653.

Chen, Y. G., Cui, X. L., Wang, Y. X., Zhang, Y. Q., Tang, S. K., Li, W. J., Liu, Z. X., Wen, M. L. \& Peng, Q. (2009). Virgibacillus sediminis sp. 
nov., a moderately halophilic bacterium isolated from a salt lake in China. Int J Syst Evol Microbiol 59, 2058-2063.

Collins, M. D., Pirouz, T., Goodfellow, M. \& Minnikin, D. E. (1977). Distribution of menaquinones in actinomycetes and corynebacteria. J Gen Microbiol 100, 221-230.

De Ley, J., Cattoir, H. \& Reynaerts, A. (1970). The quantitative measurement of DNA hybridization from renaturation rates. Eur $J$ Biochem 12, 133-142.

Duckworth, A. W., Grant, W. D., Jones, B. E. \& Steenbergen, R. V. (1996). Phylogenetic diversity of soda lake alkaliphiles. FEMS Microbiol Ecol 19, 181-191.

Dussault, H. P. (1955). An improved technique for staining red halophilic bacteria. J Bacteriol 70, 484.

Garabito, M. J., Arahal, D. R., Mellado, E., Márquez, M. C. \& Ventosa, A. (1997). Bacillus salexigens sp. nov., a new moderately halophilic Bacillus species. Int J Syst Bacteriol 47, 735-741.

Gregersen, T. (1978). Rapid method for distinction of Gram-negative from Gram-positive bacteria. Eur J Appl Microbiol Biotechnol 5, 123-127.

Groth, I., Schumann, P., Weiss, N., Martin, K. \& Rainey, F. A. (1996). Agrococcus jenensis gen. nov., sp. nov., a new genus of actinomycetes with diaminobutyric acid in the cell wall. Int J Syst Bacteriol 46, 234-239.

Heyndrickx, M., Lebbe, L., Kersters, K., De Vos, P., Forsyth, G. \& Logan, N. A. (1998). Virgibacillus: a new genus to accommodate Bacillus pantothenticus (Proom and Knight 1950). Emended description of Virgibacillus pantothenticus. Int J Syst Bacteriol 48, 99-106.

Heyndrickx, M., Lebbe, L., Kersters, K., Hoste, B., De Wachter, R., De Vos, P., Forsyth, G. \& Logan, N.A. (1999). Proposal of Virgibacillus promii sp. nov. and emended description of Virgibacillus pantothenticus (Proom and Knight 1950) Heyndrickx et al. 1998. Int J Syst Bacteriol 49, 1083-1090.

Heyrman, J., Logan, N. A., Busse, H. J., Balcaen, A., Lebbe, L., Rodriguez-Díaz, M., Swings, J. \& De Vos, P. (2003). Virgibacillus carmonensis sp. nov., Virgibacillus necropolis sp. nov. and Virgibacillus picturae sp. nov., three novel species isolated from deteriorated mural paintings, transfer of the species of the genus Salibacillus to Virgibacillus, as Virgibacillus marismortui comb. nov. and Virgibacillus salexigens comb. nov., and emended description of the genus Virgibacillus. Int J Syst Evol Microbiol 53, 501-511.

Hua, N. P., Hamza-Chaffai, A., Vreeland, R. H., Isoda, H. \& Naganuma, T. (2008). Virgibacillus salarius sp. nov., a halophilic bacterium isolated from a Saharan salt lake. Int J Syst Evol Microbiol 58, 2409-2414.

Huß, V. A. R., Festl, H. \& Schleifer, K. H. (1983). Studies on the spectrophotometric determination of DNA hybridization from renaturation rates. Syst Appl Microbiol 4, 184-192.

Kämpfer, P. \& Kroppenstedt, R. M. (1996). Numerical analysis of fatty acid patterns of coryneform bacteria and related taxa. Can $\mathrm{J}$ Microbiol 42, 989-1005.

Kumar, S., Tamura, K. \& Nei, M. (2004). MEGA3: integrated software for molecular evolutionary genetics analysis and sequence alignment. Brief Bioinform 5, 150-163.

Lee, J. S., Lim, J. M., Lee, K. C., Lee, J. C., Park, Y. H. \& Kim, C. J. (2006). Virgibacillus koreensis sp. nov., a novel bacterium from a salt field, and transfer of Virgibacillus picturae to the genus Oceanobacillus as Oceanobacillus picturae comb. nov. with emended descriptions. Int J Syst Evol Microbiol 56, 251-257.

Marmur, J. (1961). A procedure for the isolation of deoxyribonucleic acid from microorganisms. J Mol Biol 3, 208-218.

Marmur, J. \& Doty, P. (1962). Determination of the base composition of deoxyribonucleic acid from its thermal denaturation temperature. J Mol Biol 5, 109-118.
Niederberger, T. D., Steven, B., Barbier, B., Charvet, S. \& Whyte, L. G. (2009). Virgibacillus arcticus sp. nov. a halophilic spore-former isolated from permafrost in the Canadian high Arctic. Int J Syst Evol Microbiol 59, 2219-2225.

Quesada, T., Aguilera, M., Morillo, J. A., Ramos-Cormenzana, A. \& Monteoliva-Sánchez, M. (2007). Virgibacillus olivae sp. nov., isolated from waste wash-water from processing of Spanish-style green olives. Int J Syst Evol Microbiol 57, 906-910.

Sasser, M. (1990). Identification of bacteria by gas chromatography of cellular fatty acids. Technical Note 101. Newark, DE: MIDI, Inc.

Schleifer, K. H. \& Kandler, O. (1972). Peptidoglycan types of bacterial cell walls and their taxonomic implications. Bacteriol Rev 36, 407-477.

Sehgal, S. N. \& Gibbons, N. E. (1960). Effect of some metal ions on the growth of Halobacterium cutirubrum. Can J Microbiol 6, 165-169.

Smibert, R. M. \& Krieg, N. R. (1981). General characterization. In Manual of Methods for General Bacteriology, pp. 409-443. Edited by P. Gerhardt, R. G. E. Murray, R. N. Costilow, E. W. Nester, W. A. Wood, N. R. Krieg \& G. B. Phillips. Washington, DC: American Society for Microbiology.

Stackebrandt, E. \& Goebel, B. M. (1994). Taxonomic note: a place for DNA-DNA reassociation and $16 \mathrm{~S}$ rRNA sequence analysis in the present species definition in bacteriology. Int J Syst Bacteriol 44, 846849.

Thompson, J. D., Gibson, T. J., Plewniak, F., Jeanmougin, F. \& Higgins, D. G. (1997). The CLUSTAL_X windows interface: flexible strategies for multiple sequence alignment aided by quality analysis tools. Nucleic Acids Res 25, 4876-4882.

Torreblanca, M., Rodriguez-Valera, F., Juez, G., Ventosa, A., Kamekura, M. \& Kates, M. (1986). Classification of nonalkaliphilic halobacteria based on numerical taxonomy and polar lipid composition, and description of Haloarcula gen. nov. and Haloferax gen. nov. Syst Appl Microbiol 8, 89-99.

Ventosa, A., Quesada, E., Rodriguez-Valera, F., Ruiz-Berraquero, F. \& Ramos-Cormenzana, A. (1982). Numerical taxonomy of moderately halophilic Gram-negative rods. J Gen Microbiol 128, 1959-1968.

Wang, C. Y., Chang, C. C., Ng, C. C., Chen, T. W. \& Shyu, Y. T. (2008). Virgibacillus chiguensis sp. nov., a novel halophilic bacterium isolated from Chigu, a previously commercial saltern located in southern Taiwan. Int J Syst Evol Microbiol 58, 341-345.

Wang, X. W., Xue, Y. F. \& Ma, Y. H. (2009). Sediminibacillus albus sp. nov., a moderately halophilic, Gram-positive bacterium isolated from a hypersaline lake, and emended description of the genus Sediminibacillus Carrasco et al. 2008. Int J Syst Evol Microbiol 59, 1640-1644.

Wayne, L. G., Brenner, D. J., Colwell, R. R., Grimont, P. A. D., Kandler, O., Krichevsky, M. I., Moore, L. H., Moore, W. E. C., Murray, R. G. E. \& other authors (1987). International Committee on Systematic Bacteriology. Report of the ad hoc committee on reconciliation of approaches to bacterial systematics. Int J Syst Bacteriol 37, 463-464.

Yoon, J. H., Oh, T. K. \& Park, Y. H. (2004). Transfer of Bacillus halodenitrificans Denariaz et al. 1989 to the genus Virgibacillus as Virgibacillus halodenitrificans comb. nov. Int J Syst Evol Microbiol 54, 2163-2167.

Yoon, J. H., Kang, S. J., Lee, S. Y., Lee, M. H. \& Oh, T. K. (2005). Virgibacillus dokdonensis sp. nov., isolated from a Korean island, Dokdo, located at the edge of the East Sea in Korea. Int J Syst Evol Microbiol 55, 1833-1837.

Yoon, J. H., Kang, S. J., Jung, Y. T., Lee, K. C., Oh, H. W. \& Oh, T. K. (2010). Virgibacillus byunsanensis sp. nov., isolated from a marine solar saltern. Int J Syst Evol Microbiol 60, 291-295. 